\title{
Repeated historical earthquakes in Sousse, Monastir and El-Jem (Tunisia)—an archaeoseismological study
}

\author{
Miklós Kázmér ${ }^{1}$ (D)
}

Received: 19 May 2020 / Accepted: 16 December 2020 / Published online: 1 February 2021

(C) The Author(s) 2021

\begin{abstract}
Tunisia is known of sparse and moderate earthquakes. However, there are seismically damaged historical buildings in the eastern Sahel region. The Roman amphitheatre of Thysdrus (modern El-Jem), various Islamic religious and secular buildings in Sousse and Monastir testify to seismic events with intensity up to IX (EMS98 scale). We raise the hypothesis that their destruction was caused by the nearby east-west Cherichira-Abaieh Fault and the north-south Monastir Fault. Simultaneity of the 859 AD Kairouan earthquake and extensive restoration works in Sousse $50 \mathrm{~km}$ to the east allow assessing magnitude up to 7.2 based on segment length. The city was hit both by the 859 AD and a post-1575 earthquake. Being nearby two active faults, seismic hazard in Sousse is higher than either in Kairouan or in Monastir.
\end{abstract}

Keywords Archaeoseismology · Earthquake · Seismic Hazard · Tunisia

\section{Introduction}

The diffuse plate boundary along the northern margin of Africa had earthquakes up to M 7.3 during the past six decades. Tectonic activity is concentrated along transpressional folds and strike-slip faults within the coastal Atlas region, both onshore and offshore (Meghraoui and Pondrelli 2012). There is foreland deformation south of the range. The Tunisian sector is the best studied (Bahrouni et al. 2020b), having sparse and moderate seismic events up to M 4.7 since 1981, dominated by strike-slip faults (Bahrouni et al. 2014). Historical seismology, from Ambraseys (1962) to Kharrat et al. (2019), revealed that earthquakes larger than M 7 are possible (Fig. 1). Utilizing the information hidden in archaeological objects has started in archaeological circles (Kamoun et al. 1980), followed by exact seismological studies

This article is part of the Topical Collection on Seismic Hazard and Risk in Africa.

Miklós Kázmér

mkazmer@gmail.com

1 Department of Palaeontology, Eötvös University \& MTA-ELTE Geological, Geophysical and Space Science Research Group, Budapest, Hungary recently. Bahrouni et al. (2019, 2020a) offered a glimpse on archaeological evidence of the AD 859 earthquake in Kairouan.

Recently, the author carried out pilot studies in three sites in the less seismic eastern Sahel region of Tunisia: Roman Thysdrus (modern El-Jem) and in the Islamic medina (old town) of Sousse and Monastir (Fig. 1) (Kázmér 2019). Earthquake archaeological effects are illustrated below, discussed in the framework of active tectonics.

\section{Methods}

"Archaeoseismology is... a subdiscipline of paleoseismology with a particular focus on man-made constructions as a potential source of paleoseismological information covering the last few millennia" (Sintubin 2015). Various deformations in the construction fabric are recorded, surveyed and dated within the framework of the individual history of the building. Intensity values are assigned to damage features following the scheme of Rodríguez-Pascua et al. (2013). Sites were studied by visual observation and documented by photography and hand drawings. Measurements were taken by Laser Disto 8 and TriPulse 360B range finders, allowing quick measurement of horizontal and vertical distances. 


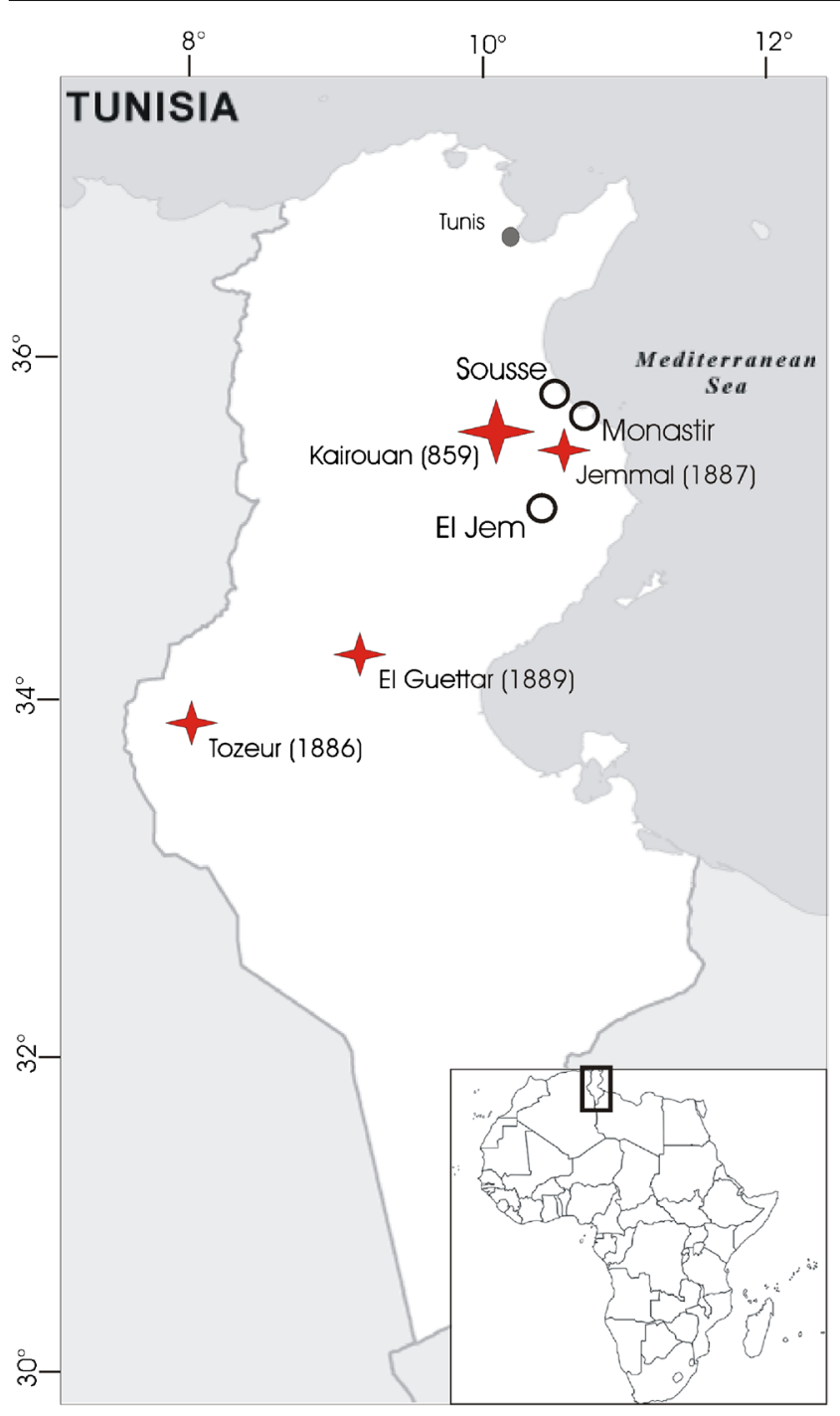

Fig. 1 Destructive historical earthquakes in Tunisia. Circles mark locations of studied sites in the present paper. Large star: Kairouan earthquake of intensity IX-X (Bahrouni et al. 2020a). Smaller stars mark locations of VIII $<\mathrm{I}_{0}<$ IX historical earthquakes (Kharrat et al. 2019). Base map downloaded from http://www.mapsopensource.com/tunisiacapital-map-black-and-white.html. Creative Commons Attribution 3.0 license. Accessed 22 November 2020

\section{Results}

\section{Thysdrus (El-Jem) amphitheatre}

Thysdrus (modern El-Jem or El-Djem) was the rich centre of olive growing in Tunisia in Antiquity, briefly rising to the rank of imperial capital in the AD 230s. Huge public works constructed during its heyday include an impressive, freestanding amphitheatre, which remained the largest and best preserved one in the whole Roman empire except those in Rome and Capua. Construction probably started by Emperor Gordian III in 238 AD. It was repeatedly used for defence purposes in the 5th century against the Vandals and in the 7th century against the Arab conquest. It was a fortress during the revolutions in Tunis in 1695, when cannons were used to break a hole in the wall. It hosted a saltpetre factory in the 1819th century. Major restoration works were carried out between 1975 and 1980. The amphitheatre is UNESCO World Heritage site since 1979 (Slim 1986, 1996; Slim and Rebourg 1995).

The oval building is $148 \mathrm{~m}$ long and $122 \mathrm{~m}$ wide. The preserved perimeter wall is $31 \mathrm{~m}$ high. Walls are made of sandstone masonry, hiding Roman concrete within. The southern half of the amphitheatre seems more or less intact at first glance. The external wall is missing in the east, while most sectors of the northern half disappeared (Fig. 2). Serious structural damage is visible upon close inspection. Majority of arches are damaged: keystones and entire segments dropped (Fig. 2b). Voussoirs (blocks of masonry arches) bear penetrating fractures (Fig. 2c). More of the radial arches seem to be damaged than the tangential arches, although this needs further field studies to confirm. Arches on the upper floors tend to be more damaged than on lower floors. Second- and third-tier arches are often missing (collapsed). There are no arches preserved in the topmost level (Fig. 2d).

\section{Sousse}

\section{Ribat}

Modern Sousse, underlain by Roman Hadrumetum, boasts quite a few monuments listed as UNESCO World Heritage. The old town, the medina, its walls and the enclosed fortress, the ribat guarding the coast, the Grand Mosque, the hilltop fortress: the kasbah, seat of the local governor and many other buildings are some of Tunisia's oldest Islamic constructions.

A ribat is principally a religious institution, dedicated to propagating the good word of Islam. In exchange for privileges, the ascetic inhabitants were entrusted with the surveillance of the coastline to prevent landing of attacking Byzantine fleets. Ribats were members of a chain of watchtowers along the shore of Northern Africa, keeping guard and giving fire or smoke signals from the tower. The ribat of Sousse is the oldest Islamic monument in the city (Fig. 3a). It was founded between 775 and $788 \mathrm{AD}$. The watchtower was added in 812 (Laporte 2015:24). It underwent several repairs; finally, it was turned into a madrasa (religious college) in 1721. Much of the material used in the building was reclaimed from older buildings of Antiquity (2nd to 6th century): marble columns and capitals were taken from Roman temples. All of the surviving columns are of this provenance. Walls rest on the foundations of a Christian basilica (Djelloul 2007a).

The entrance gate, in the middle of the southern facade, is covered by a porch (Fig. 3b). There are two spolia columns 

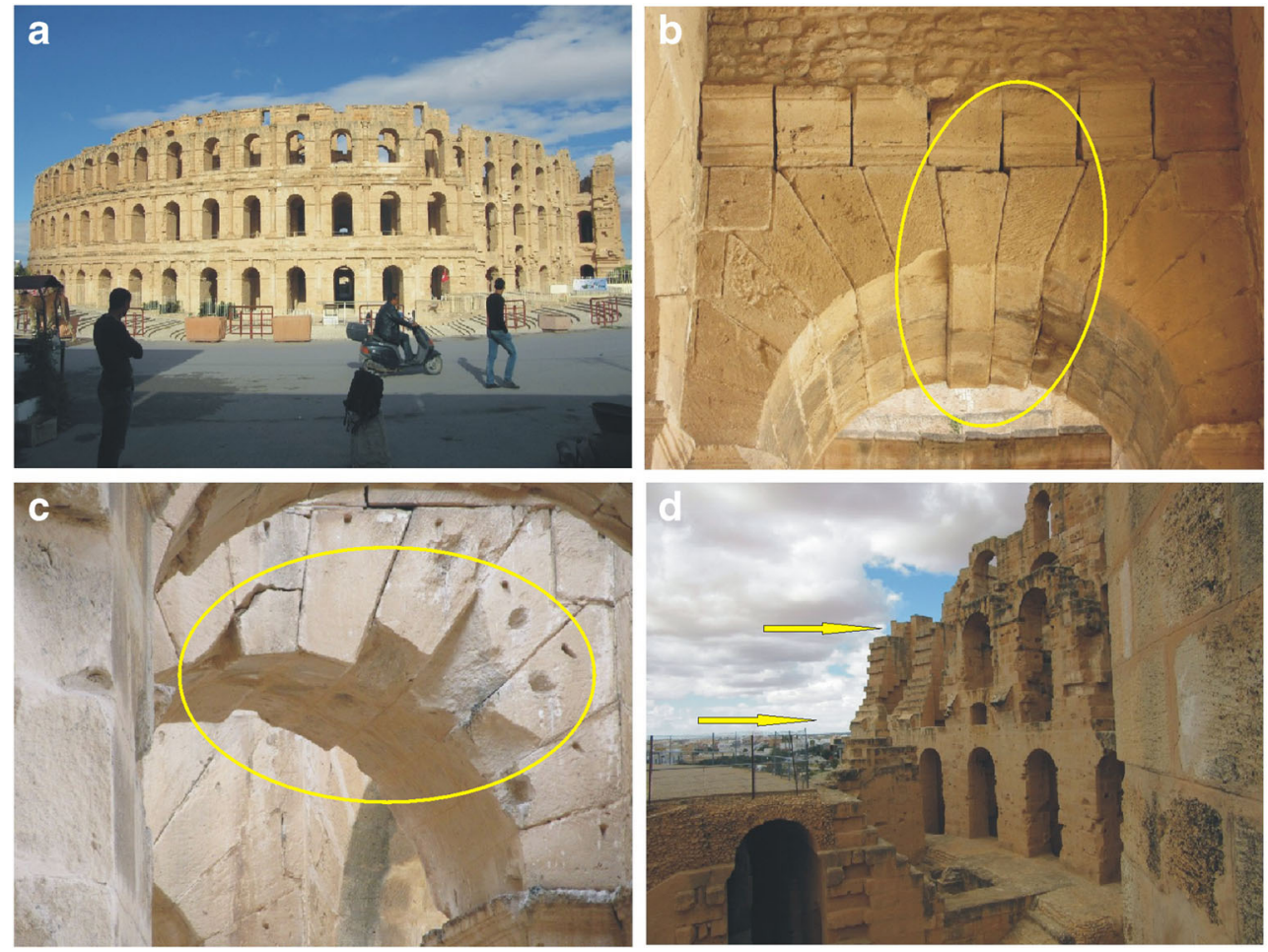

Fig. 2 Evidence for damaging earthquake affecting the Roman amphitheatre of Thysdrus (modern El-Jem). a Amphitheatre, viewed from SE. \#5953. b Displaced arch segment: the keystone and another voussoir on the right (encircled) shifted downwards during repeated extension and compression of corridor walls during earthquake. I = VII+. \#6083. c Penetrating fractures in arch masonry, parallel to lateral stress:

(Greenhalgh 2011) flanking the gate: the left one is well-preserved, white marble, the right one is heavily weathered and light brown granite. Two isometric capitals of different Corinthian decoration top the columns, testifying that these were also removed from Roman buildings. The building was used for various purposes during the centuries, involving major architectural modifications. However, the structural organisation as seen today is essentially the same as it was in the late 8th century. Contemporary restoration made the building look like new. However, upon careful observation, one can find evidence for seismic damage: these items are briefly described below.

The marble column on the left of the main gate bears a special broken surface (Pollard and Aydin 1988: his Fig 10B): conchoidal rib marks with rounded profile indicate progress of jointing parallel with column axis, from bottom to top. This fracture was caused by repeated collision between column and plinth during vertical shaking (Fig. 3f). We are studying the exact mechanism of these axis-parallel fractures in columns (Besharatinezhad et al. 2020) to reveal whether static or shaking-induced dynamic loading is the cause.

Further, damaged constructional elements are the broken lintel above the gate (Fig. 3d), and a sunken arch segment above the stairs leading from the second floor to the

in-place voussoirs fractured by horizontal hammering of adjacent blocks (in circle). I = VII+. \#6098. d Collapsed vaults of the second- and thirdfloor perimeter corridors. Arch springers are visible (arrows). I = IX. \#6103. EMS98 intensity is assigned after Rodriguez-Pascua et al. (2013). Photo numbers refer to the Archaeoseismological Database (Moro and Kázmér 2020). 35 $17^{\prime} 47^{\prime \prime} \mathrm{N}, 10^{\circ} 42^{\prime} 25^{\prime \prime} \mathrm{E}$

observation tower (Fig. 3c). Two marble columns on the ground floor entrance hall are damaged: a conspicuous fracture, parallel with oriented texture, cuts through across a marble column obliquely (Fig. 3e). This is a structural weakness, which did not visibly affect the integrity of the column at the time of construction. This damage is probably but not certainly due to seismic attack.

The ribat is now dated to the late eighth century on archaeological grounds. It is generally assumed that it was built by the Muhallabid governor (ruled 772-788) (Fenwick 2018:213).

\section{Great mosque}

The great mosque, the largest religious building in Sousse, was built in 851 AD (Fig. 4a). The prayer hall and courtyard might be a bit later, but still from the 9th century. Subsequently, an arcaded portico was added, probably in 1575 (Terrasse 2014). The only suspicious deformations found are on the columns of the arcade. There are vertical penetrative fractures parallel with column axis: up to $25 \mathrm{~cm}$ wide, up to $70-\mathrm{cm}$-high splinters of the stone columns are missing, replaced by concrete (Fig. 4b). Seven out of 12 columns are fractured, displaying preferred orientation, facing 
Fig. 3 Evidence for damaging earthquake affecting the Islamic ribat in Sousse. a The Sousse ribat. View from SE. \#5789. b Main gate in entrance porch (see detail of left column, broken, on Fig. 4f). \#5790. c Dropped arch segment on top of the staircase leading to the observation tower. \#5844. I = VII+. d Broken and repaired lintel above the main gate. \#5801. I = VII. e Textureparallel fracture in marble column near in the entrance room right behind the gate. $\# 5810 . \mathrm{I}=\mathrm{VII}+\mathbf{f}$ Penetrating fracture through column and plinth (in circle).

Conchoidal ribs indicate progress of fracture from below. \#5795. I = VII+. EMS98 intensity is

assigned after Rodriguez-Pascua et al. (2013). $35^{\circ} 49^{\prime} 40^{\prime \prime} \mathrm{N}, 10^{\circ}$ $38^{\prime} 20^{\prime \prime} \mathrm{E}$
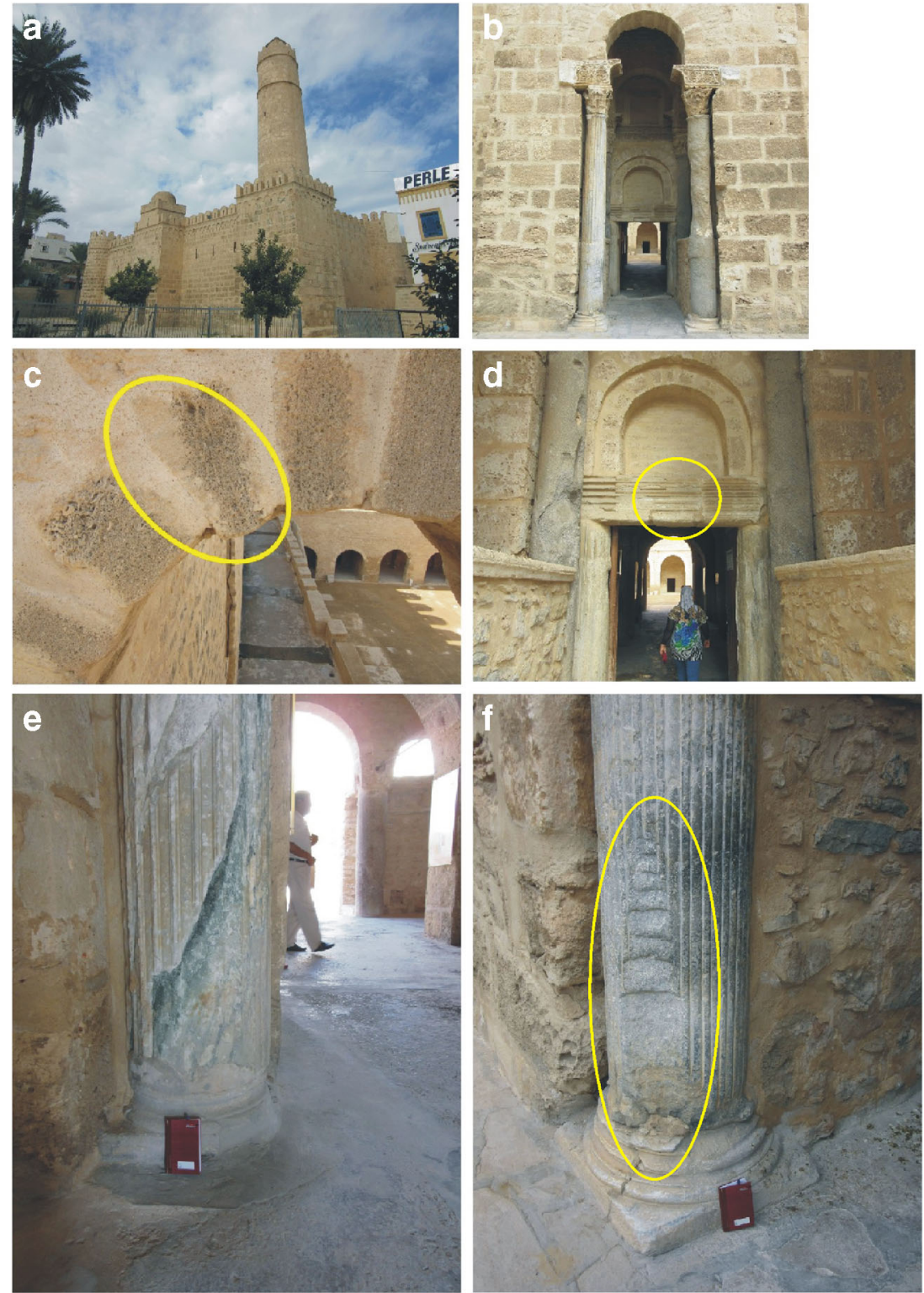

either northwest or southeast (Fig. 4c). The origin of longitudinal and oblique fractures is interpreted as hammering by adjacent architectural elements, in this case by the plinth below. Longitudinal fracture is caused by axial shock, acting parallel with the column axis. Oblique fracture is caused by oblique shock, when the column deviates from the vertical during seismic shaking (Kázmér 2013; Besharatinezhad et al. 2020).

\section{Kasbah}

In Sousse, the first kasbah, the city fort, seat of the governor, was built in 844-845 (Fenwick 2018:213). It was increased to a much larger one, as seen today, in 859 AD (Laporte 2015: 425) (Fig. 5a). Bahrouni et al. (2020a, their Fig. 7c) reported that the southwestern tower bears a conspicuous vertical fracture extending from the top almost down to the foundation (Fig. 5d). There are four marble towers at the entrance to the museum. These have been displaced off their respective plinths (Fig. 5b). The northwestern column "walked off" its foundation almost halfway in northwestern direction (Fig. 5c). The tower and all the kasbah-built of smaller-sized masonry-were rebuilt after the destruction, but the columns - the most expensive, hard-to-obtain elements of the building-were left in place, as they still served their supporting role well.

\section{City wall}

City walls are usually built less carefully than religious buildings and fortresses. These were rebuilt repeatedly, both after natural calamities and after every attack and destruction. 


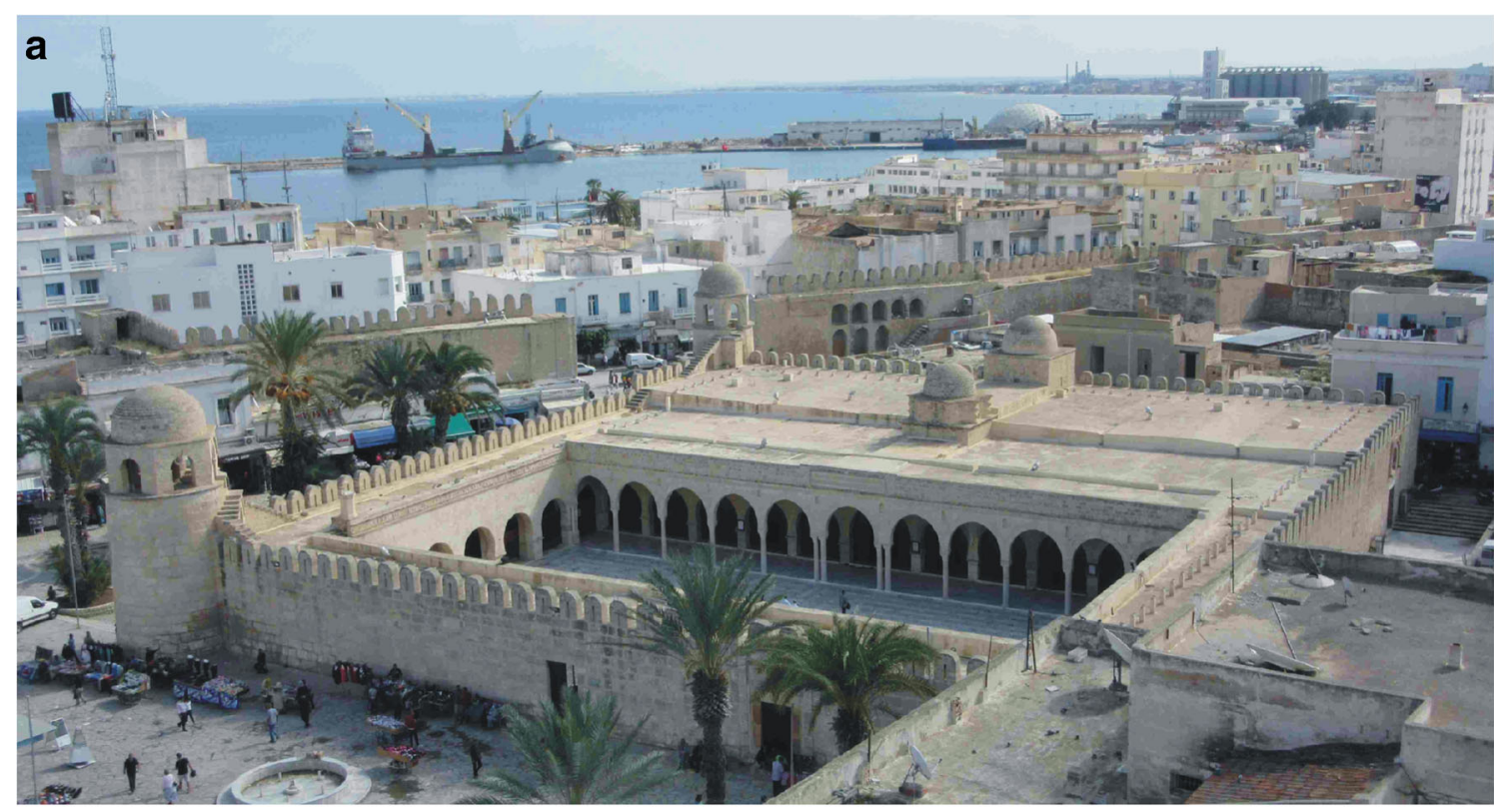

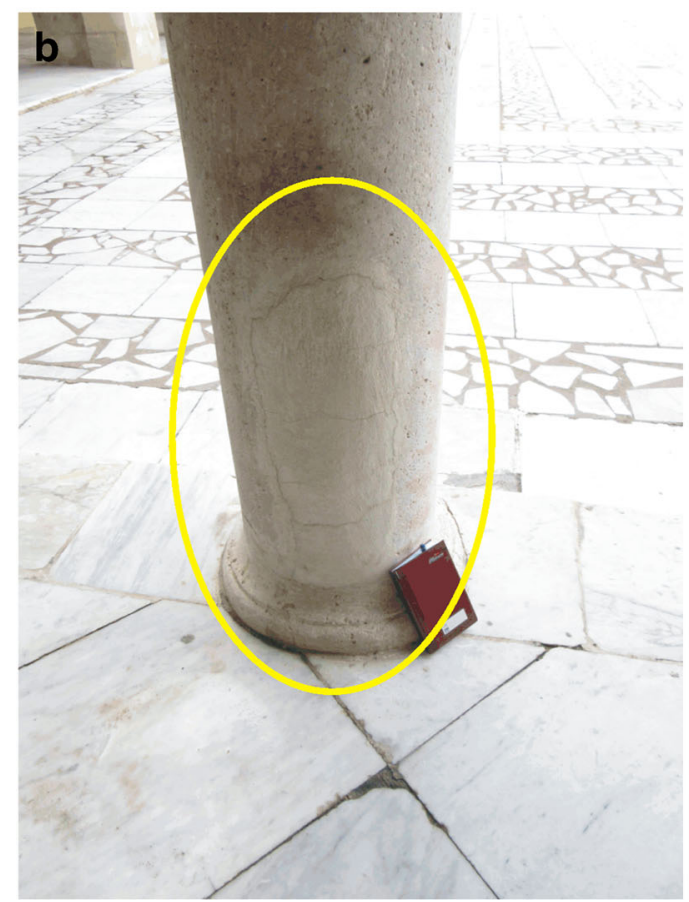

Fig. 4 Evidence for damaging earthquake affecting the Great Mosque in Sousse. a Great mosque as seen from the observation tower of the ribat. \#5848. b $50 \mathrm{~cm}$ high longitudinal fracture, repaired (encircled), in the slender sandstone columns in the 17 th century portico of the Great

Therefore, each sector has a different age, which is often impossible to date.

The medina of Sousse is surrounded by an intact wall. Gates provide access to the old town within. It was probably completed in 859 (Fenwick 2018: 13). Fortunately, it has at least one portion which is well dated by an inscription. This is a memorial to the person who rebuilt the wall in AD 859-860) (Bahrouni et al. 2020a: their Fig. 7a).

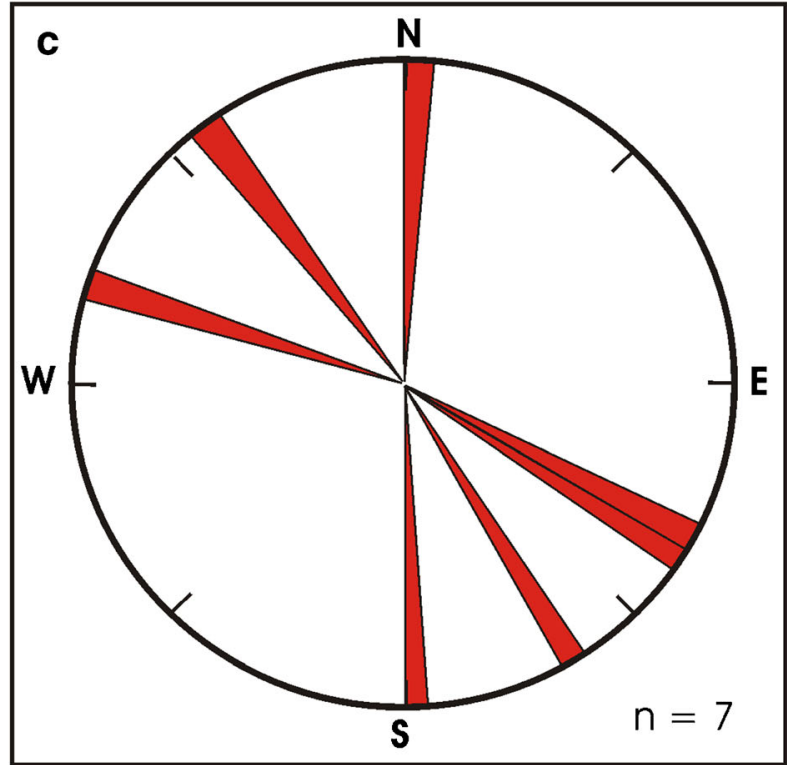

Mosque. \#5889. I = VII+. c Preferred orientation of axis-parallel fractures on columns is facing NW or SE. Each petal represents one fracture. EMS98 intensity is assigned after Rodriguez-Pascua et al. (2013). $35^{\circ}$ $49^{\prime} 37^{\prime \prime} \mathrm{N}, 10^{\circ} 38^{\prime} 23^{\prime \prime} \mathrm{E}$

Here, we provide data on actual damage of undated portions of the city wall: the southern gate is tilted outwards (Fig. 6a). A collapsed and rebuilt portion of the wall is illustrated by Bahrouni et al. (2020a, their Fig. 7b). An inward tilted portion and the adjacent, reconstructed part is illustrated on Fig. 6c. There is a deformed arch in an undated portion of the wall (Fig. 6b): voussoirs on the left are sunken relative to the right. 
Fig. 5 Evidence for damaging earthquake affecting the kasbah in Sousse. a View of the huge fortress from northeast. \#5857. b Both marble columns on the right and left are shifted on their respective plinths (encircled). \#5926. I = IX. c Figure NW column at the kasbah museum entrance, shifted on the plinth by $22 \mathrm{~cm}$ in northwestern direction. \#5928. I = IX. d Tower on the southwest corner is fractured vertically (arrow) (see also Bahrouni, 2020a: Fig. 7c). \#5915. EMS98 intensity is assigned after Rodriguez-Pascua et al. (2013). $35^{\circ} 49^{\prime} 22^{\prime \prime} \mathrm{N}, 10^{\circ} 38^{\prime} 09^{\prime \prime} \mathrm{E}$
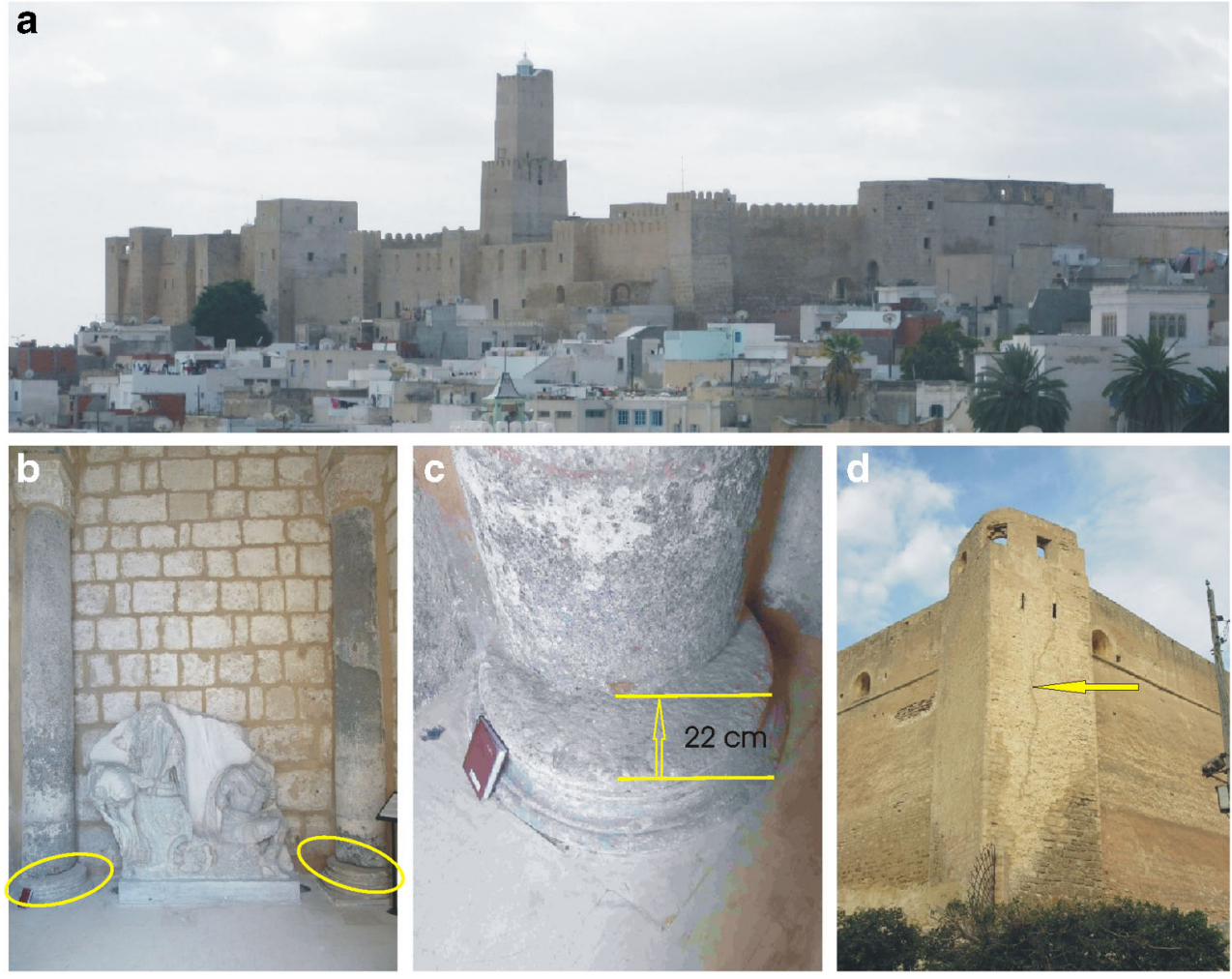

\section{Monastir}

\section{Ribat}

The fortress of Monastir had similar, military and religious purposes than the ribat of Sousse. It is much bigger, bearing evidence for several construction and reconstruction phases (Djelloul 2007b) (Fig. 7a). The core was built during the Abbasid dynasty in AD 796 (Fenwick 2018: 2016). The western wing with columnar gate is Hafside period (13-16th century). Modifications to military and religious functions followed each other from the 16th century onwards. Repeated consolidation and repair works were carried out in the 20th century. A detailed study for earthquake damage is needed; here, a few conspicuous details are shown.

The western tower has a second gate, flanked by two marble columns, and an arched portico above (Fig. 7b). The western column within the gate displays a fracture, about $90 \mathrm{~cm}$ high, parallel with column axis. The broken-off splinter is missing; its place is left unrepaired (Fig. 7c). This fracture is very similar to that seen on the column of the ribat gate in Sousse (Fig. 3f) and to several, repaired fractures in the Great Mosque of Sousse (Fig. 4b). After fracturing, the column was displaced, "walking off" the plinth. There are some more displaced columns within the fortress, e.g. the one on the first floor (Fig. 7d). Detailed knowledge of construction history is needed before interpretation can be given.

\section{City walls}

When the ribat was built in 795 , Monastir was a town of importance, with strong connections to other ports by sea. This certainly necessitated surrounding the settlement with a protective wall. No data on its construction was found, however. Possibly, it is more or less the same age as the wall around the medina of Sousse: 9th century. The southern gate (Fig. 8a) seems to be intact. However, on close examination, one finds a conspicuous fracture dissecting the arch from top to bottom, displacing nicely carved, adjacent blocks by maybe 2-3 cm or less (Fig 8b).

\section{Discussion}

\section{Seismic origin of damage}

Ambraseys (2006) warned us to examine all possible ways of destruction before resorting to seismic origin. Here, we discuss alternative mechanisms.

Keystone drop in arches is the most reliable evidence of earthquake excitation. Computer modelling by Kamai and Hatzor (2008) revealed that a single element or a set of elements (a segment) of an arch can drop only under repeated compression and extension, i.e. transient horizontal ground motion (Hinzen et al. 2016). In each extensional step, the 
Fig. 6 Evidence for damaging earthquake affecting the city wall in Sousse. a Misfit of city gate and adjacent wall: gate tower tilted outwards. The wall on the right is vertical. There is misfit between adjacent masonry. \#5902. 354941.2 N, 103818.3 E. b City wall, deformed arch. Voussoirs on the left shifted downwards (encircled). \#5867. I $=$ VII. $35^{\circ} 49^{\prime} 36^{\prime \prime} \mathrm{N}, 10^{\circ} 38^{\prime}$ 24.5" E. c Twisted/tilted city wall on left (arrow), vertical restoration on the right. $\# 5897 . \mathrm{I}=$ VIII. $35^{\circ}$ $49^{\prime} 41.5^{\prime \prime} \mathrm{N}, 10^{\circ} 38^{\prime} 21.3^{\prime \prime} \mathrm{E}$. EMS98 intensity is assigned after Rodriguez-Pascua et al. (2013)
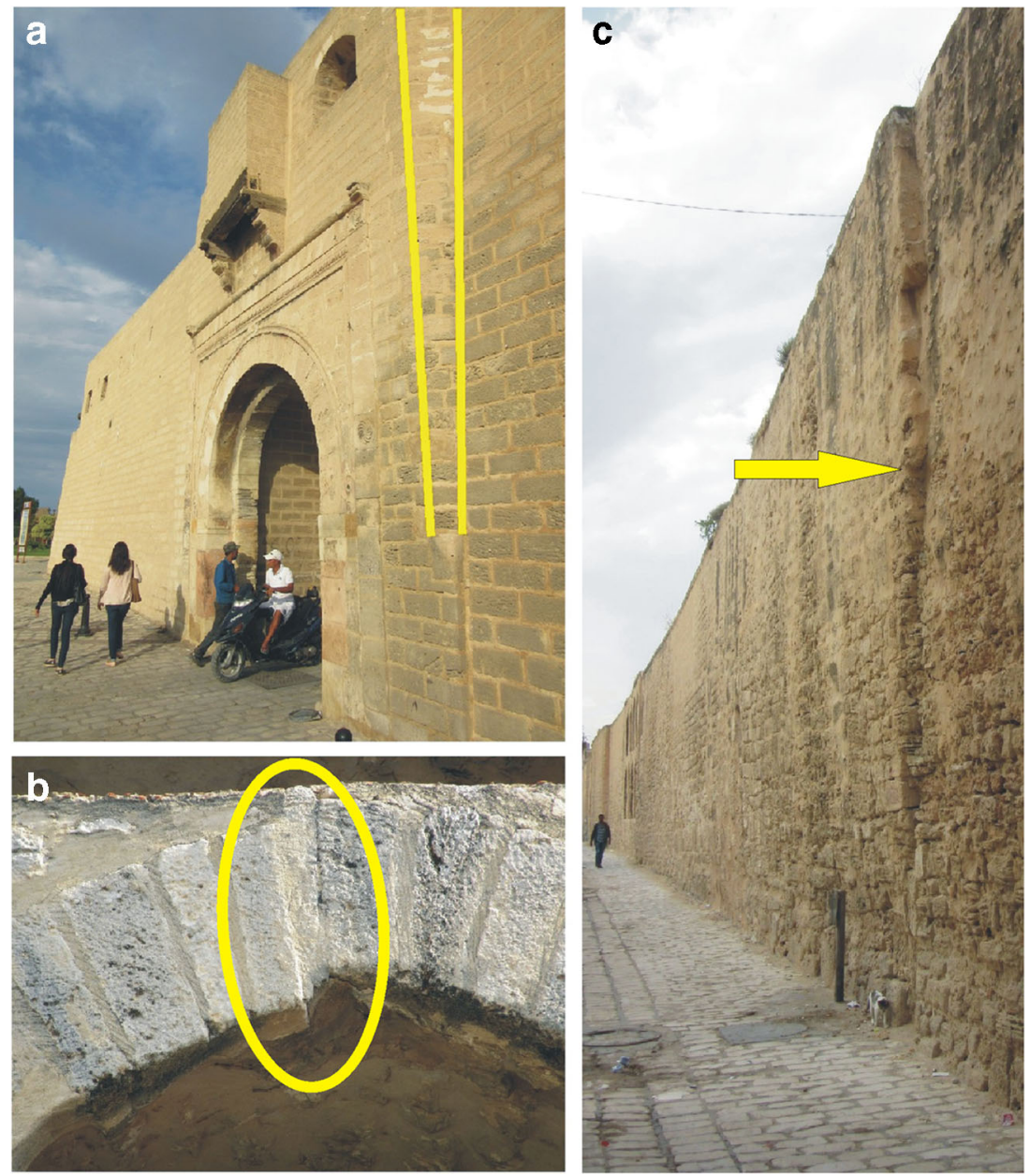
Fig. 7 Evidence for damaging earthquake affecting the ribat in Monastir. a The Hafside tower is in the middle of the western facade. View from SW. \#6130. b Polygonal Hafside gate tower built at around 1424. View from south. Column on Fig. $8 \mathrm{c}$ is on the left of the gate. \#6131. c Axial fracture broke both the column and the plinth. Subsequently, the column "walked" excentrically (arrow). \#6134. I = IX. d

Eccentrically displaced column on the upper floor of the ribat. Column asymmetrically displaced from plinth (circle). \#6161. I = IX. EMS98 intensity is assigned after Rodriguez-Pascua et al. (2013). $35^{\circ} 46^{\prime} 33 \cdot 3^{\prime \prime} \mathrm{N}, 10^{\circ}$ $498^{\prime} 57.7^{\prime \prime} \mathrm{E}$
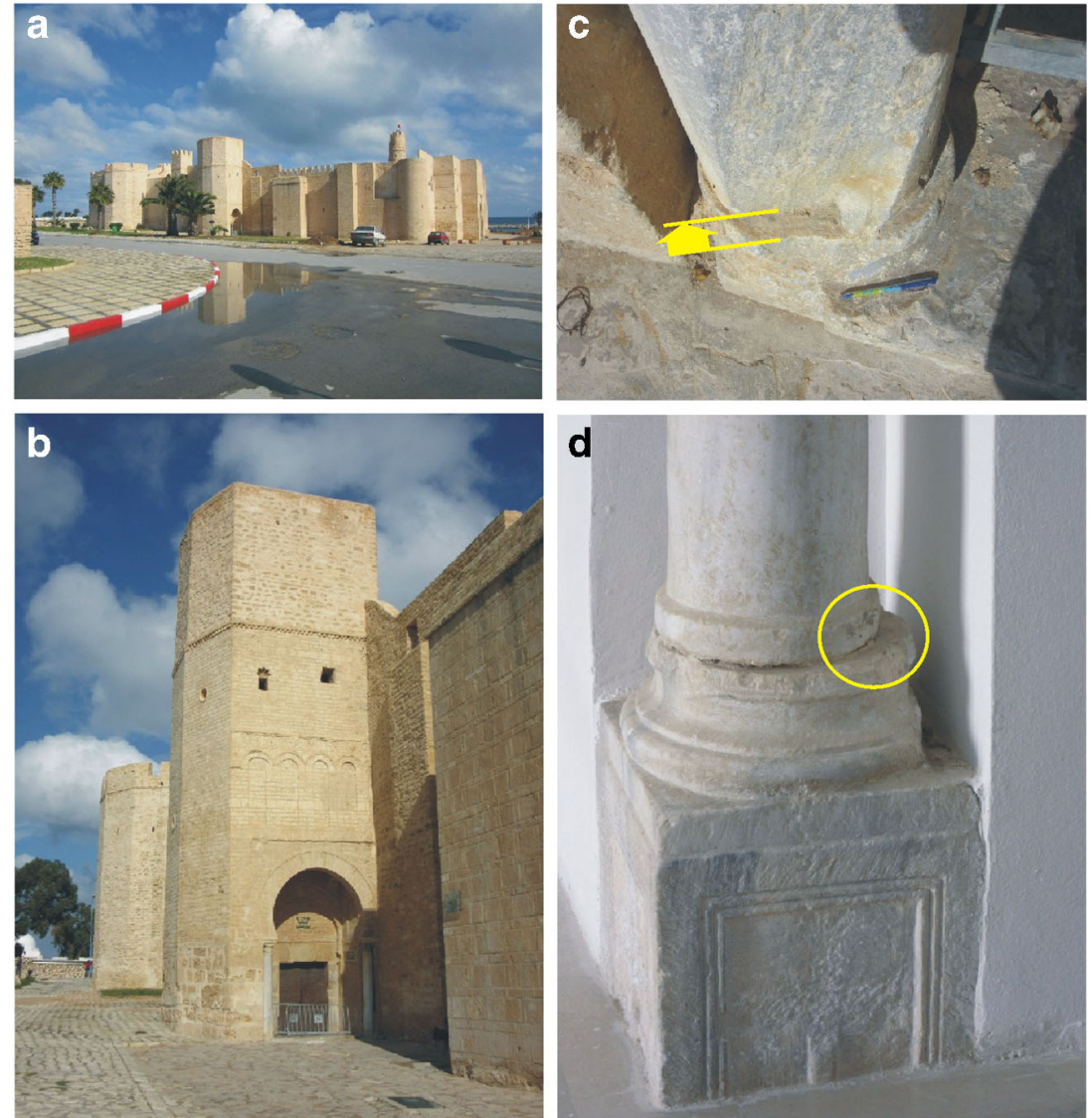

could be damaged any time after its construction, which started in AD 238. There is ample amount of structural damage; however, there is no evidence of any major reconstruction to the original function. As there is no visible evidence of repair beyond the modern restoration in 1975-1980, we can put that there were neither financial means nor social need to rebuild the amphitheatre after the earthquake. Thysdrus ceased to be an imperial centre after the death of Gordian III in 244 AD. We know that circus games (certainly in amphitheatres) were arranged - even during Christianity - as late as in the fifth century, during the time of Augustine of Hippo (354-430 AD) (Augustine lived in Hippo, i.e. modern Annaba in Algeria). Circus shows set in amphitheatres were still the ways of public entertainment in his times of which he condemned (Brown 2000: 194). The economy behind the richness of Thysdrus probably disappeared a few centuries later when Kahina, a Romano-Berber queen, destroyed most of the olive trees around the city in $695 \mathrm{AD}$, but probably much earlier. The remaining building was still used for defense purposes repeatedly. Troops of the Bey of Tunis attacked it with artillery in 1695 and in the middle of the 19th century. Material of collapsed parts was re-used in constructing nearby buildings.

Was the Thysdrus amphitheatre damaged by the AD 859 Kairouan earthquake or by another one? An important source to be considered is Kitāb al-Masālik wa-al-Mamālik ("Book
Fig. 8 Slightly damaged arch of the southern gate to the medina, Monastir. a Monastir, medina, southern gate. \#6193. b Left part of gate subsided. Displacement extends up to the ledge, going around all masonry blocks (circle). \#6194. I = VII. $35^{\circ} 46^{\prime}$ $22^{\prime \prime} \mathrm{N}, 10^{\circ} 49^{\prime} 50^{\prime \prime} \mathrm{E}$
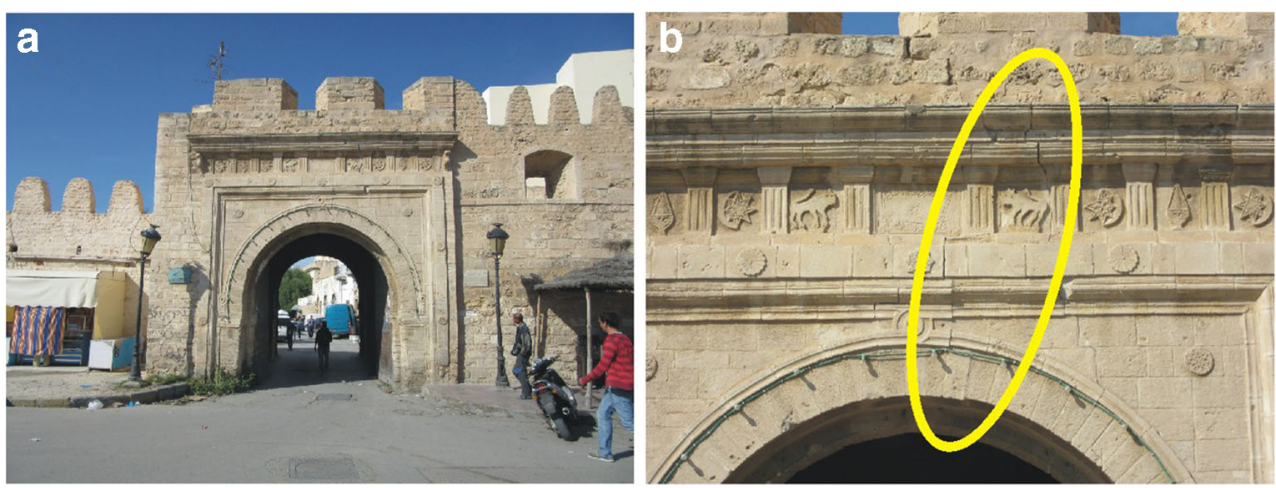


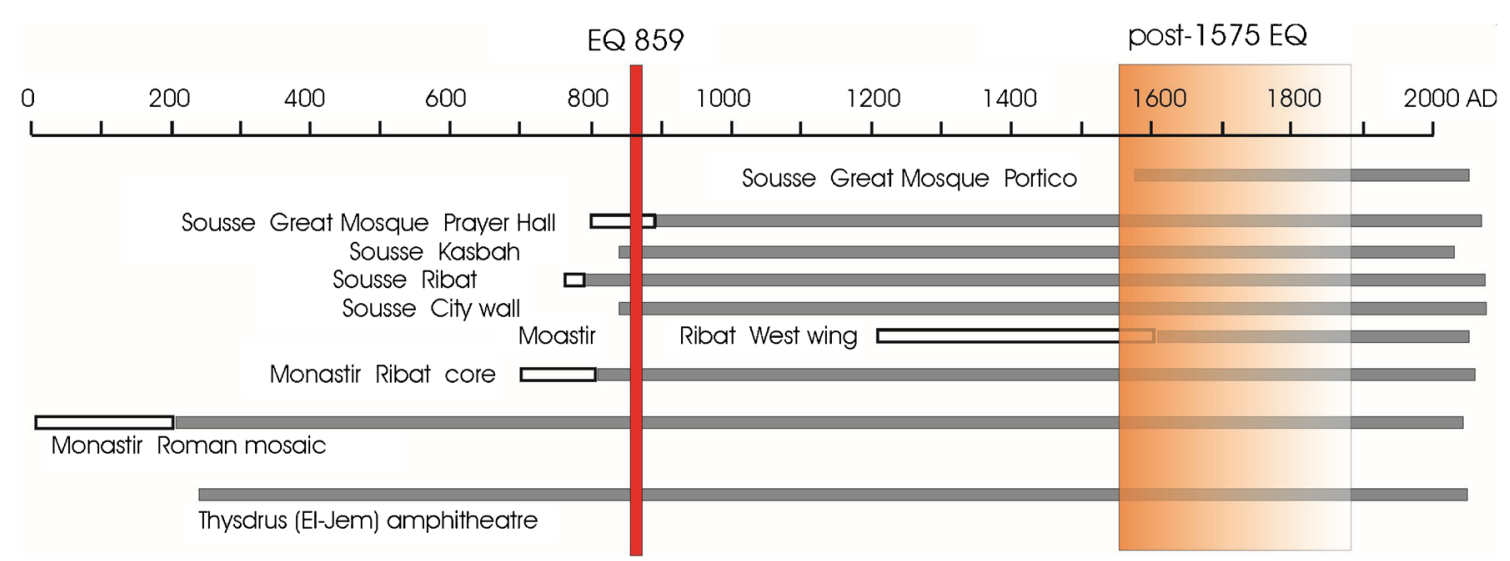

Fig. 9 Date of known (859 AD) and suspected (post-1575 AD) destructive earthquakes in the Sahel zone of Tunisia, based on archaeoseismological data. Grey lines: the named building certainly existed during this period. White lines: the named building possibly existed during this period

of Highways and of Kingdoms") of Al-Bakri, the greatest geographer of the Muslim West. He reported it as follows: "Ledjem fortress... about a mile in circumference ... built of stones, many of which are about twenty-five spans long. Its height is twenty-four toises; the entire interior is arranged in tiers, from bottom to top; the doors are semicircular and placed one above the other with perfect craftsmanship" (Al-Bakri 1859: 52, translated from the French version of Slane).

Al-Bakri spent his entire life in Al-Andalus (AD 10401094), without ever having travelled to the locations of which he wrote. He used various manuscripts in compiling his treatise, some more recent than others. However, it is less probable that he would use two-centuries-old sources describing El-Jem. His description (his unnamed source's description) is so precise, so vivid: we can easily believe that there was no major damage to the amphitheatre in the 11th century. All or most walls were still standing and the cavea was not yet robbed of the rows of seats. Any major damage to the building potentially occurred later than the
AD 859 Kairouan earthquake, and possibly later than the 11 th century.

Collapse of the now missing perimeter walls and missing sectors in the north could be caused by either the 1695 or the mid-19th century siege, or by seismic shaking any other time after Al-Bakri's 11th century description. Collapse of vaults and arches is certainly due to earthquake(s).

\section{Sousse}

There is a debate, started by Di Vita $(1980,1982)$ and Foucher (1982) on a supposed earthquake affecting Hadrumetum (modern Sousse) 306-31 AD; the problem is still unsolved (Vogt 1993).

None of the buildings studied are suitable for direct archaeological dating. The most certain archaeological datum comes from an inscription on the Sousse city wall, marking its reconstruction in AD 859-860 (Bahrouni et al. 2020a: their Fig. 7a). It is known that there was a major earthquake which destroyed

Table 1 Construction time of Antique and medieval monuments in Sousse, Monastir and El-Jem, and the date of known earthquakes in reverse temporal order (all dates AD).

\begin{tabular}{|c|c|c|c|}
\hline Site & Earthquake name & Construction/completion time of buildings & Earthquake date \\
\hline & Monastir-Sousse EQ & & $<1575$ \\
\hline Sousse, Great Mosque, portico & & $1575 ?$ & \\
\hline Monastir, ribat, western wing & & 13-16th century & \\
\hline & Kairouan-Sousse EQ & & 859 \\
\hline Sousse, kasbah and city wall completed & & $<859$ & \\
\hline Sousse, Great Mosque, prayer halls & & 9th century & \\
\hline Sousse, Great Mosque & & 851 & \\
\hline Monastir, ribat & & $8 \mathrm{ct}$ & \\
\hline Sousse, ribat & & $775-788$ & \\
\hline Thysdrus (El-Jem) amphitheatre & & $<238$ & \\
\hline Monastir, Roman mosaic & & $1-2$ nd century & \\
\hline
\end{tabular}


much of Kairouan and 13 villages around in that year. Therefore, this monumental inscription most certainly marks completion of rebuilding the city wall after that calamity. All other dating attempts yielded a wide interval for the destruction event at most (Table 1).

The columns in the Sousse ribat were certainly damaged by an earthquake. It could happen any time after construction was completed in AD 788. The first candidate is the $859 \mathrm{AD}$ Kairouan earthquake. The post-1575 earthquake also probably affected the kasbah.

The kasbah was completed right before the 859 AD Kairouan earthquake. This-or another-seismic event certainly severely damaged the fortress, shifting columns of the entrance almost off their foundation. The 859 earthquake is a likely candidate here, so is the post- 1575 event.

Fractured columns of the portico arcade in the great mosque indicate an earthquake after the construction date of 1575. Its date is unknown yet. We are not aware of any other destruction which certainly happened at this time.

\section{Monastir}

Tunisia is famous for floor mosaics from Roman times. One of these, nearby Monastir, was laid down in the first or second century AD. It suffered deformation subsequently: both folding and faulting affected the floor. It was first interpreted in tectonic terms by Kamoun et al. (1980), Kamoun (1981), and Sorel et al. (1983). A left-lateral strand of the N-S Monastir Fault displaced it by $15 \mathrm{~cm}$ (Bahrouni et al. 2014:245 and their Fig. 4c; Ghribi et al. 2018, their Fig. 7).

The ribat of Monastir was built in the 8th century. There is various, obviously earthquake-induced damage in the building. Lacking access to detailed construction history, one can refer to the dated western wing. Built in the 13-16th century, the entrance column suffered damage subsequently, certainly after the 16th century, possibly as early as the 13th century. The damage (fractured column) is severe, but did not hinder usage of the building.

The modern earthquake, which damaged the west wing of the Monastir ribat and the 1575 portico of the great mosque in Sousse, probably occurred before colonial administration started by the establishment of the French protectorate in 1881; therefore, no historical account was found yet.

\section{Intensity}

An EMS98 intensity value is assigned to each and every documented earthquake damage feature. Assignment is based on the study of Rodríguez-Pascua et al. (2011) describing Earthquake Archaeological Effects (EAE), and correlating with the MMS98 intensity scale (Rodríguez-Pascua et al. 2013). Maximum estimated intensity for Thysdrus amphitheatre is IX (collapsed arches), for Sousse IX (shifted column) and for Monastir also IX (shifted columns).

The current instrumental records of seismic activity nearby Sousse contain up to M 4.5 earthquakes (Table 2, Fig. 10) (Bahrouni et al. 2014). Historical M 6-7 earthquakes are known in Tunisia elsewhere (Ksentini and Romdhane 2014; Kharrat et al. 2019). Bahrouni et al. (2014) indicate two faults in close proximity to Sousse: the west-east trending Cherichira-Abaied Fault (F5) and the north-south trending Monastir Fault (F6).

Along the Monastir Fault (Skanes-Khnis Fault; Ghribi et al. 2018), the maximum measured earthquake had magnitude $M$ 4.7. There was no surface rupture during this event in 2013. However, displacement of Tyrrhenian terraces allows to hypothesize $M_{\mathrm{w}} 6.3$ earthquakes every 263 years (Ghribi et al. 2018).

Surface rupture of a historical earthquake caused a $15-\mathrm{cm}$ left-lateral displacement in a 2nd century Roman mosaic (Bahrouni et al. 2014:245; Ghribi et al. 2018: their Fig. 7). Such a displacement is in accordance with the damage observed on the marble columns of the ribat there.

\section{Magnitude}

\section{The $859 \mathrm{AD}$ earthquake}

Historical documents recorded a major earthquake in Kairouan on 9 October 859 AD. An inscription in Sousse marks reconstruction of a portion of the city wall dated 859 860 AD (Bahrouni et al. 2020a). If really the same seismic event hit both cities, it means major damage in places $50 \mathrm{~km}$ apart. If we consider the destructed Cherichira aqueduct $20 \mathrm{~km}$ to the west of Kairouan (Bahrouni et al. 2020a), then the total distance is $70 \mathrm{~km}$. It is very possible that displacement along an at least $70 \mathrm{~km}$ long segment of the east-west

Table 2 Focal mechanism parameters of three earthquakes along the Cherichira-Abaied Fault, indicating right-lateral strike-slip displacement (after Bahrouni et al. 2014, modified). For locations on a tectonic map, see Fig. 11

\begin{tabular}{|c|c|c|c|c|c|c|c|c|c|}
\hline & Date & Time & Lat. & Long. & Strike & Dip & Slip & Magnitude & Depth \\
\hline A & 30 January 1995 & 21 h 17 & $35^{\circ} 51^{\prime}$ & $10^{\circ} 20^{\prime}$ & 165 & 90 & -143 & 4.5 & 6 \\
\hline B & 4 February 1995 & 11 h 38 & $35^{\circ} 52^{\prime}$ & $10^{\circ} 29^{\prime}$ & 085 & 70 & 141 & 4.0 & 6 \\
\hline $\mathrm{C}$ & 1 February 1995 & 17 h 11 & $35^{\circ} 53^{\prime}$ & $10^{\circ} 32^{\prime}$ & 010 & 55 & -137 & 4.1 & 4 \\
\hline
\end{tabular}




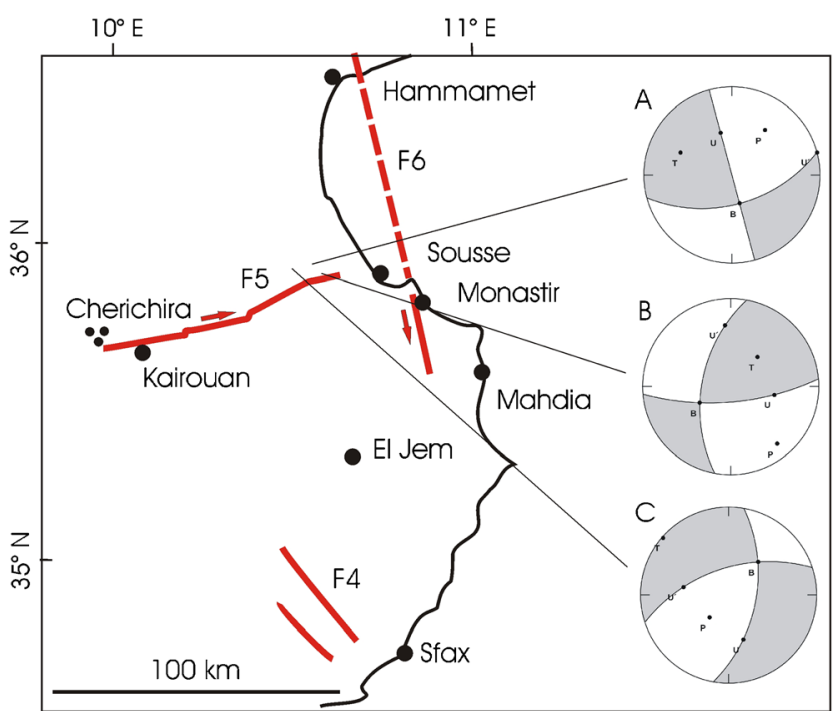

Fig. 10 Seismic and tectonic activity in the Sahel region of Tunisia (after Bahrouni et al. 2014, strongly simplified). F4: Agareb Fault. F5: east-west Cherichira-Abaied Fault. F6: north-south Monastir (Shaknes-Khis) Fault. Earthquake focal mechanisms (Schmidt's projection, lower hemisphere, compressional dihedron: white colour, extensional dihedron: black colour) of M 4.0-4.5 earthquakes in early 1995 indicate right-lateral strike-slip displacement along the Cherichira-Abaied Fault. The Monastir Fault (F6) is left-lateral

Cherichira-Abaied Fault caused simultaneous destruction in both cities. Using the correlation between segment length and magnitude of Wells and Coppersmith (1994), it can be an earthquake of M 7.2 magnitude.

\section{The post-1575 AD earthquake}

There are seismically damaged buildings both in Sousse and Monastir, erected well after 859 AD: the Great Mosque and the west wing of the Monastir ribat, respectively. If the same earthquake damaged both cities, $20 \mathrm{~km}$ apart, then a minimum 20-km-long segment of the Monastir fault caused the earthquake, yielding a minimum magnitude M 6.3. These are realistic assessments, not worst-case scenarios.

It is possible that both the E-W and the N-S fault slipped in different time. Both affected Sousse, making the site seismically more hazardous than either Kairouan or Monastir.

\section{Conclusions}

There are high number of seismically damaged buildings in the eastern Sahel region of Tunisia. The Roman amphitheatre of Thysdrus (modern El-Jem), various Islamic religious, and secular buildings in Sousse and Monastir testify to past earthquakes of intensity IX, caused by the nearby east-west Cherichira-Abaieh Fault and the north-south Monastir Fault. The 859 AD Kairouan earthquake probably affected Sousse $50 \mathrm{~km}$ to the east (but not El-Jem amphitheatre), allowing to assess magnitude up to 7.2. Sousse was hit by both the 859 $\mathrm{AD}$ and a post-1575 earthquake. Being nearby two active faults, seismic hazard in Sousse is higher than either in Kairouan or Monastir.

Acknowledgements Sincere thanks are due to Abderrahim Smari (Sousse) for assistance in the field. International Geological Correlation Programme IGCP-659 (Seismic Hazard and Risk in Africa) supported the presentation of results at the 2nd Conference of Arabian Journal of Geosciences in Sousse, Tunisia, on 24-29 November 2019. Two anonymous reviewers and special issue editor Mustapha Meghraoui are thanked for their supporting comments.

Authors' contributions $100 \%$ by single author.

Funding Open Access funding provided by Eötvös Loránd University. Private funding of the author.

Data availability Data are included in the manuscript.

\section{Compliance with ethical standards}

Conflict of interest The authors declare that they have no conflict of interest.

Code availability Not applicable.

Open Access This article is licensed under a Creative Commons Attribution 4.0 International License, which permits use, sharing, adaptation, distribution and reproduction in any medium or format, as long as you give appropriate credit to the original author(s) and the source, provide a link to the Creative Commons licence, and indicate if changes were made. The images or other third party material in this article are included in the article's Creative Commons licence, unless indicated otherwise in a credit line to the material. If material is not included in the article's Creative Commons licence and your intended use is not permitted by statutory regulation or exceeds the permitted use, you will need to obtain permission directly from the copyright holder. To view a copy of this licence, visit http://creativecommons.org/licenses/by/4.0/.

\section{References}

Al-Bakri (1859) Description de l'Afrique septentrionale par El-Bekri. Traduite par Mac Guckin de Slane. Imprimerie Imperiale, Paris

Ambraseys N (1962) The seismicity of Tunis. Annali di Geofisica 15: 233-244

Ambraseys NN (2006) Earthquakes and archaeology. Journal of Archaeological Science 33:1008-1016

Bahrouni N, Bouaziz S, Soumaya A, Ben Ayef N, Attafi K, Houla Y, El Ghali A, Rebai N (2014) Neotectonic and seismotectonic investigation of seismically active regions in Tunisia: a multidisciplinary approach. Journal of Seismology 18:235-256

Bahrouni N, Meghraoui M, Hinzen K, Arfaoui M, Maamri R, Mahfoud F (2019) Historical and archeoseismic investigations in Kairouan region (central Tunisia): evidence for the 9 October 859 AD large earthquake. 2nd Conference of the Arabian Journal of Geosciences, 25-28 November 2019, Sousse, Tunisia (in press)

Bahrouni N, Meghraoui M, Hinzen K, Arfaoui M, Mahfoud F (2020a) The damaging earthquake of 9 October 859 in Kairouan (Tunisia): 
evidence from historical and archeoseismological investigations. Seismological Research Letters 91:1890-1900. https://doi.org/10. 1785/0220190258

Bahrouni N, Masson F, Meghraoui M, Saleh M, Maamri M, Dhaha F, Arfaoui M (2020b) Active tectonics and GPS data analysis of the Maghrebian thrust belt and Africa-Eurasia plate convergence in Tunisia. Tectonophysics 785:228-240

Besharatinezhad A, Török Á, Al-Tawalbeh M, Kázmér M (2020) Modelling of seismicity-induced cracking of stone columns using discrete-element-method (DEM), a case study of Eufrasius cathedral, Porec, Croatia. European Geosciences Union, General Assembly, 3-8 May 2020, Vienna, Austria. Abstract EGU202010462. 10.5194/egusphere-egu2020-10462

Brown P (2000) Augustine of Hippo. A Biography. University of California Press, Berkeley

Di Vita A (1980) Evidenza dei terremoti de 306-310 e del 365 d. C. in Tunisia. Antiquités Africaines 15:303-307

Di Vita A (1982) Evidenza dei terremoti del 306-310 e del 365 in monumenti e scavi di Tunisia, Sicilia, Roma e Cirenaica. Africa $7-8: 127-139$

Djelloul N (2007a) The Sousse ribat. Éditions de l'Agence e mise en valeur du patrimoine et de Promotion Culturelle, Tunis

Djelloul N (2007b) The Monastir ribat. Éditions de l'Agence e mise en valeur du patrimoine et de Promotion Culturelle, Tunis

Fenwick C (2018) Early medieval urbanism in Ifriqiya and the emergence of the Islamic city. In: Panzram, S., Callegarin, L. (eds): Entre civitas y madīna. El mundo de las ciudades en la Península Ibérica y en el norte de África (siglos iv-ix), Collection de la Casa de Velázquez (167), Madrid, 2018, pp. 203-220

Foucher L (1982) Le tremblement de terre de 306-310 en Tunisie (Hadrumete). Bulletin Archéologique o Comité des Travaux Historiques et Scientifiques, fasc. A

Ghribi R, Zaatra D, Bouaziz S (2018) Quaternary activity of the Monastir and Grombalia fault systems in the north-eastern Tunisia (seismotectonic implication). Geotectonics 52:100-113

Greenhalgh M (2011) Spolia: A definiton in ruins. In: Brilliant, R., Kinney, D. (eds): Reuse Value. Spolia and Appropriation of Art and Architecture from Constantine to Sherrie Levine. Routledge, London, pp. 75-96.

Hinzen K-G, Schwellenbach I, Schweppe G, Marco S (2016) Quantifying earthquake effects on ancient arches, example: the Kalat Nimrod fortress, Dead Sea Fault Zone. Seismological Research Letters 87: 751-764

Kamai R, Hatzor YH (2008) Numerical analysis of block stone displacements in ancient masonry structures: a new method to estimate historic ground motions. International Journal for Numerical and Analytical Methods in Geomechanics 32:1321-1340

Kamoun Y (1981) Etude néotectonique dans la région de MonastirMahdia (Tunisie orientale). Thèse Doc. 3ème cycle, Univ. Paris XI, Centre d'Orsay

Kamoun Y, Sorel Y, Viguier C, Ben Ayed N (1980) Un grand accident subméridien d'âge post-Tyrrhénien en Tunisie orientale: le décrochement sénestre de Skanès (Monastir)-Hammamet. Comptes Rendus de l'Académie des Sciences Paris Series D 290: 647-649

Kázmér M (2013) The rocking columns of Poreč - archaeoseismology in the Istria Peninsula, Croatia. In: Grützner, C., Rudersdorf, A., PérezLópez, R., Reicherter, K. (eds): Seismic Hazard, Critical facilities and Slow Active Faults. PATA Days. Proceedings of the 4th International INQUA Meeting on Paleoseismology, Active Tectonics and Archaeoseismology (PATA), 9-14 October 2013, Aachen, Germany, pp. 117-120

Kázmér M (2019) Why seismic hazard is underestimated in Tunisia. An archaeoseismological study. 2nd Conference of the Arabian Journal of Geosciences (CAJG) 25-28 November 2019, Sousse, Tunisia (in press)

Kharrat S, Harbi A, Meghraoui M, Bouaziz S (2019) The Tunisia homogenized macroseismic database (second century - 1981): first investigations. Seismological Research Letters 90:347-357

Ksentini A, Romdhane NB (2014) Updated seismic hazard assessment of Tunisia. Bulletin of Earthquake Engineering. 12:647-670

Laporte J-P (2015) D'Hadrumete a Sousse, des années 350 a 859. RM2E Revue de la Mediterranéenne, édition électronique Tome II. 1:3-34

Meghraoui M, Pondrelli S (2012) Active faulting and transpression tectonics along the plate boundary in North Africa. Annals of Geophysics 55:955-967

Moro E, Kázmér M (2020) Damage in ancient buildings - towards an archaeoseismological database. Annals of Geophysics (In preparation)

Pollard DD, Aydin A (1988) Progress in understanding jointing over the past century. Geological Society of America Bulletin 100:11811204

Rodríguez-Pascua MA, Pérez-López R, Giner-Robles JL, GarduñoMonroy VH (2011) A comprehensive classification of Earthquake Archaeological Effects (EAE) in archaeoseismology: application to ancient remains of Roman and Mesoamerican cultures. Quaternary International 242:20-30

Rodríguez-Pascua MA, Silva PG, Pérez-López R, Giner-Robles J-L, Martín-González F, Perucha MA (2013) Preliminary intensity correlation between macroseismic scales (ESI07 and EMS98) and Earth-quake Archaeological Effects (EAEs). In: Proceedings of the 4th International INQUA Meeting on Paleoseismology, Aachen, 221-224

Sintubin M (2015): Archeoseismology. In: Beer M, Patelli E, Kouigioumtzoglou I, Au I S-K (eds): Encyclopedia of Earthquake Engineering, Springer, Berlin, 133-146

Slim H (1986) Les amphitheatres d'El-Djem. Comptes Rendus des Séances de l'Académie des Inscriptions et Belles Lettres, 130:440 469

Slim H (1996) El Djem. L'antica Thysdrus. ALIF, Les Éditions de la Méditerranée, Agence Nationale du Patrimoine, Tunis

Slim H, Rebourg A (1995) El Jem. Site archéologique et musée. Les guides Cérés. Cérés Editions, Tunis

Sorel D, Kamoun Y, Sayadi MS, Viguier C, Ben Ayed N (1983) Décrochement d'âge historique et risque sismique dans la région de Monastir (Tunisie orientale). Note de Service Géologique de Tunisie 47:35-41

Terrasse M (2014) Lieux de Priere a Sousse au haut Moyen Age: modeles ou énigmes. RM2E Revue de la Méditerranée édition electronique. Tome I 1:3-10

Vogt J (1993) Further research on the historical seismicity of Tunisia. Terra Nova 5:475-476

Wells DL, Coppersmith KJ (1994) New empirical relationships among magnitude rupture length, rupture width, rupture area, and surface displacement. Bulletin of the Seismological Society of America 84: 974-1002 